\title{
TOPOGRAPHY IN THE TIMAEUS: PLATO AND AUGUSTINE ON MANKIND'S PLACE IN THE NATURAL WORLD
}

In this paper I shall be considering the relationship between the shape or structure of the world and the moral position occupied by human beings, particularly with regard to man's attitude towards and use of the natural resources of the material world he inhabits.

\section{The shape of the world}

There are two basic spatial metaphors that we frequently use in analysing notions of value and morality: one is the scale of up and down, with high and low or top and bottom as alternative ways of referring to the same type of hierarchy; the other is the notion of a centre, the bull's eye: if we are self-centred we value ourselves more highly than other things; if we have an anthropocentric view we value humanity above other animals. Thus we usually suppose that we put whatever we value most highly (on the one set of metaphors) at 'the centre of things' (on the other set).

It is tempting to suggest that these spatial metaphors might actually be reflected in our theories about the structure of the world. It will be apparent from what $I$ argue in this paper that a plausible case might be made for the "high and low' set of metaphors having some bearing on ancient pictures of the world; but my focus of attention is actually on the 'centre of things' set of metaphors, in connection with ancient theories of a centrifocal universe.

If we have an anthropocentric view of the world it is surely likely that we shall cling to the idea that man's place in the cosmos is literally central too, on a planet that is similarly important for having a central position in a well-ordered cosmos created to revolve around it. Such a view is implied (though not fully explored) by David Furley in his recent book on the Greek cosmologists. ${ }^{1}$ At the start he contrasts the view prevalent today (and adumbrated by the atomists in antiquity), in which our earth is merely one of many planets round a minor star in an infinite universe, with the more traditional view that the earth was central in a finite world. 'So the species man..., observes Furley on page 1 of the book, 'being the best of the creatures that live near the centre of the whole universe, has a uniquely privileged position'. 
This beautifully plausible theory, that the centrifocal universe was centred on man both literally and metaphorically, looks like a neat explanation of the history of science and astronomy. Just as we like to draw our maps with ourselves at the centre (or just above the centre) so we liked to draw our world with ourselves near the centre. How easy it is then to explain why it was so long before a heliocentric theory could replace the old geocentric one. It was not, after all, the authority of the bible that was challenged by Aristarchus, Copernicus and Darwin: it was our own self-centred view of the purpose and structure of creation. Because our understanding of the world and our place in it was, perhaps inevitably (poor primitive thinkers we were then) anthropocentric, we could not envisage good order in the cosmos and us not in the centre. It was only natural, then, that we should find it hard to picture ourselves on a petty planet pottering round a minor star in an infinite centreless universe. Given evolution, we could not even think of it as 'our earth' since we were late arrivals and less numerous than the aphids or bacteria at whose mercy we live.

There is a note of self-congratulation in this account of the history of astronomy, though to maintain the myth we should probably hesitate to express it. Have we not grown out of the self-centred attitude to the natural world that insisted on mankind's place in the middle of things? We can pride ourselves on the objectivity of our view: unlike them we are manifestly free from the prejudice that follows from such distortion of the truth. On this myth we at least gain superiority if not centrality.

For now, however, the subject for attack is not the modern picture of the world, but the ancient one, or more precisely the claim that man's place in that view was central or focal. In the structurally centrifocal material world of Plato and his ancient companions, is man privileged for his place at the centre of things? Is the focus of value the centre of the natural world?

\section{Plato's Timaeus}

Plato's Timaeus is a dialogue largely dominated by a speech not from Socrates but from Timaeus of Locri. Timaeus is a stranger not from mainland Greece but from the West; he comes from Southern Italy. The dramatic location of the dialogue is Athens, since Socrates is always at home in Athens, but the philosophical centre of the world has shifted.

A. This shift of focus is emphasized by the dramatic framework of the dialogue.

(1) It begins by recalling the discussion of the previous day. ${ }^{2}$ No one can fail, and no one has failed, to recognize in this summary the contents of Plato's Republic. In the Republic as we know it Socrates takes a leading rôle; in the recapitulation that supposedly took place on the day before the Timaeus Socrates' rôle must have been even more predominant. Socrates had outlined to 
his guests the main features of his political theory. ${ }^{3}$ Today, by contrast, it is Timaeus' turn to speak; $;^{4}$ after Timaeus Critias will take over ${ }^{5}$ and after Critias Hermocrates. ${ }^{6}$ Socrates has left the centre of the stage and there is no prospect of him returning.

(2) Athens too is no longer the centre of the world. Solon, the great Athenian, is pictured in Egypt, ${ }^{7}$ discovering that time and memories go back much longer than any Greek had ever envisaged. Just as post-Darwinian man finds himself an afterthought, so Solon learns that all Greeks are young and ignorant. ${ }^{8}$ Egyptian traditions go back further, although temporal priority actually goes to Athens which was founded a thousand years before the city of Sais in Egypt. ${ }^{9}$

All this serves to stress that the present generation of Athenians is relatively unimportant. Attention shifts back rapidly in time to a distant past before Deucalion's flood, and a generation of antediluvian Athenians who were great and powerful. Temporally our focus has shifted from the centrality of the present to the beginning of human civilization; but that past was not weaker and more primitive, but greater and more powerful. Chronologically we are not allowed to remain self-centred.

(3) The same thing happens to the spatial location of Athens. Critias' brief summary of the myth of Atlantis stresses the revamping of our geography that it requires. ${ }^{10}$ It is no accident that Atlantis lay outside the pillars of Hercules, beyond the boundaries of the known world; that it was vast, larger than Libya and Asia combined; and that it was merely an island en route to a larger and further continent beyond the Atlantic ocean. Suddenly we find that the Mediterranean is not the centre of the world, but a small lake off the main ocean. Athens is far from the centre and strikingly small in size. Our whole view of earth's geography has had to be refocussed, in a way analogous to that which displaced the earth from the centre of the universe with the advent of modern astronomy.

Nevertheless although Athens is spatially off-centre its position of importance has not been abandoned. It is chosen by the goddess Athena as a perfect location for the greatest and finest race of men, the finest institutions and the best achievements. ${ }^{1}$ Although small and marginal very ancient Athens is victorious in its struggle against the invasion from Atlantis. Beauty and greatness reside not in the centre of the world but at the edges.

(4) Socrates and Athens have thus been relegated to the margins, both spatially and temporally. It is also worth observing that the group of interlocutors is dislocated. The dialogue opens by counting the participants: "one, two, three but where is the fourth?' 12 This dramatically emphasizes the absence of one of yesterday's group from the scene in the present dialogue. This colleague is never named and we never meet him, but he does have a part to play and Timaeus and the others agree to play that rôle for him. We are thus left with a tension between the coherence of the group that is the focus of attention, and the detachment of 
the absent colleague whose influence is external and invisible. There is a sense in which this marginalized character is the first on the scene.

B. Dramatically the characters in the dialogue are off-centre. Structurally too the dialogue is asymmetrical and ambivalent about where its focus lies. Much of the dialogue is taken up with Timaeus' long monologue on which most scholars have focussed. Nevertheless that monologue is not the whole of the dialogue, nor is it central; it is not framed by the conversation with Socrates and the others, since they do not speak again at the end. The dialogue ends abruptly with the completion of the Demiurge's work.

Timaeus' speech is in this sense off-centre, preceded by eleven Stephanus pages of introductory discussion. Does this introduction focus the dialogue's attention on Timaeus' cosmology? Not at all. It starts by looking back to the conversation of the day before concerning the ideal state. Apparently the focus of interest is to be on politics; that interest is to be pursued further. ${ }^{13}$ Socrates proceeds to suggest that the topic for this dialogue is to be the ideal state in action, not merely in theory, ${ }^{14}$ and Critias goes on to outline the myth of Atlantis which is to be the subject of his speech in the Critias, the dialogue that comes next in what was to have been a trilogy. Timaeus' speech, we find, is somehow central but it is not focal: placed between yesterday's account of the Republic and next time's story of Atlantis, nevertheless within the dialogue it is displaced to one end, and within the trilogy it is marginal, a mere preliminary to the real subject. The dialogue is two faced, looking back to the Republic and forward to a more practical political discussion. Cosmology appears in the middle not for its own sake but for its contribution to the main theme. It is not independent but dependent. ${ }^{15}$

C. The structure of the world created in Timaeus' speech corresponds with the structure of the dialogue it is embedded in. Here too the focus of interest is not at the centre but at the edges and outside the material world altogether. The world described is spherical ${ }^{16}$ and it has a centre which is occupied by the earth ${ }^{17}$ (or strictly speaking coincides with the centre of the earth). The world as a whole is declared good, greatest, best, fairest and most perfect; ${ }^{18}$ it does have value but that value derives from its relationship to something outside itself, and is not located at the centre of the physical structure.

In the Timaeus Plato breaks with traditional natural science in positing a creator god, the Demiurge. ${ }^{19}$ To make the world this craftsman looks to a paradigm in the likeness of which the world is to be. ${ }^{20}$ The effect of these two moves is to create a world that is wholly dependent on things outside itself, and directed to them as goals. ${ }^{21}$ Thus while Timaeus insists on the need for the world to be self-sufficient, ${ }^{22}$ even that self-sufficiency is derivative, given by the craftsman in imitation of the independence of the paradigm it is to resemble. 
Both the world-soul and the world-body are created spherical or as a series of circles round the same centre ${ }^{23}$ and the centre of the soul coincides with the centre of the body of the universe. ${ }^{24}$ Perhaps we might expect that this centre locates a common focus of value for soul and body, but that would be incorrect. Goodness is the purpose of the world and the motivation of the Demiurge, ${ }^{25}$ but the focus of that goodness resides primarily in the soul which is prior both in order of creation and in arete, ${ }^{26}$ and within the soul it is not the centre that determines its tendency to good but the perimeter, where the motion of 'the same' is located. ${ }^{27}$ In a spherical universe the centre defines not the highest but the lowest place, so that centrifocal metaphors conflict with the high and low set of value terms. In Plato's cosmos we should not be surprised to find that importance and significance is attached not to the central location but to the outer edges.

The hierarchy of living beings follows the same spatial arrangement. First and best are the gods whose place is primarily in the stars, ${ }^{28}$ following the perfect motion of the Same at the outer edges of the cosmos, and looking to the Demiurge as father since it was at his hands that they came to be. ${ }^{29}$ Thus the focus of their gaze is outward rather than inwards.

Second in the scale of living beings comes man. His place as the first of the remaining creatures again does not derive from his central location in the universe. On the contrary his home is on the stars, ${ }^{30}$ with the gods at the outer edges. He comes first because he is the work of the Demiurge and the gods combined $^{31}$ and because he includes both mortality and immortality. ${ }^{32}$

Other creatures, and that includes woman of course, ${ }^{33}$ are not directly the work of divine craftsmen, but result from the failure of man to keep his gaze fixed on the intelligible reality. The more stupid they are, the more legs they have to attach them to the Earth. ${ }^{34}$ Stupidity starts with the failure to recognize material explanations as merely sunaitia, accessory causes and not true causes..$^{35}$ There is thus a link between the structure of reality, the nature of causal explanation and the position of man between the beasts and the gods. The closer to earth mankind gets, the further he gets from divinity and intelligence and the more importance he gives to material explanations of things.

Timaeus' speech is the first of the trilogy because his subject is the beginning of time. Time, however, as we discover at $37 \mathrm{c}$, is measured from its beginning in a linear progression, despite its attempt to imitate eternity in the unending rotation of circular heavens. It has a 'was', and a 'will be', but it cannot be centrifocal because its centre is always shifting. ${ }^{36}$ The beginning of time is important not because of its centrality but because it is a boundary, where eternity and time are marked off from one another. Timaeus' story focusses its attention on boundaries, between time and eternity, being and becoming, fact and fiction. ${ }^{37}$

Man does have a place of importance because he too is on a boundary line. Created part by the Demiurge and part by the creatures of the Demiurge he is naturally located on the perimeter of the world where the stars and the circle of 
the Same measure off time from eternity. Timaeus' own story earns its significance in the same way: it is the beginning, first in a sequence of three, and it perches precariously on the boundary between fact and fiction. Because it is about coming-to-be it can be no more than a 'likely story', the $\varepsilon \dot{i k \omega} \varsigma \mu \tilde{v} \theta 0 \varsigma$ of $29 \mathrm{~d} 2$. As if to emphasize the problematic status of Timaeus' myth, Critias' tale of Atlantis is commended by Socrates for its uncomplicated truth. The story of Atlantis is an $\dot{\alpha} \lambda \eta \theta$ ivò $\varsigma \lambda$ ó $\gamma \circ \varsigma$, not a fictitious $\mu \tilde{v} \theta 0 \varsigma, 26 \mathrm{e} 4-5.38$

Thus it should be clear that Plato's spherical universe does not give man a place of preeminence because he is at the centre of it, since he is not. Nor is man's purpose, or that of the world, located in man himself. Man has importance because he stands on the edge of the world between the material world and its immaterial telos. Plato's world is not closed and inward looking, but breaks out across its outer limits. It is not centrifocal but centrifugal in its teleological orientation.

\section{Augustine}

If Plato's cosmos ceases to look comfortably anthropocentric, perhaps man's place at the centre of things is preserved in the Christian tradition? A brief glance at Augustine will clarify how we are to understand the purpose of the created world and man's place in it, in his view.

'Use the world', says Augustine in the Tractates on John (40.10). It is important that we use the world because it must be treated as means, not ends. All human vice amounts to treating means as ends and ends as means; ${ }^{39}$ the world is definitely a means to an end, not an end in itself. This sort of argument might lead us to the conclusion that Augustine advocated an unscrupulous use of natural resources: nature was made for man's benefit, to be consumed by him in pursuit of his own ends. Augustine has sometimes been blamed, perhaps not wholly unreasonably, for modern ecological problems.

In practice Augustine may be the source of later anthropocentric attitudes to the natural world, but if so this is almost certainly a mis-reading of his argument. Two points will serve to clarify why Augustine's position is not as unscrupulous as it sounds: the first concerns the distinction between use and abuse, and the second the distinction between man-centred and god-centred ends.

\section{(a) the use/abuse distinction}

When Augustine argues that everything was created to be useful to mankind, ${ }^{40}$ he reaches his conclusion that it was only after making certain refinements in our understanding of what usefulness is. Firstly, only rational creatures can use anything, and among rational creatures only those who actually know the right end for which they should use it. If you do not know the purpose for which the 
thing is to be used you will not use it but abuse it. Hence to say that the world was made for the use of man is also to say it is not for man to abuse. It does not mean that any use for any purpose is justified. Utilitas is only that usefulness which serves our proper goals, goals known only to the wise.

\section{(b) God-centred goals}

Furthermore these goals, which the wise understand as the purpose of the world, are not directed to man's enjoyment of the world. God alone is the proper goal to be enjoyed. Proper use of the world has to be God-centred, using it to further man's need to enjoy god.

This means that the world is not there to be used for the sort of exploitation for material gain that we are accustomed to. Material gain is not the point; living it up and taking what you can of the world's resources is not Augustine's ideal. Using it to make money would be quite inappropriate. ${ }^{41}$ It is worth observing that Augustine's claim that the world is made for the use of man is not as unscrupulous or man-centred as it sounds, since the 'use of man' is to serve his divine and not his human goals.

All this might still suggest that Augustine's view of the natural world was basically anthropocentric. Even if he does make God the final goal, all that the natural world is there for seems to be to help mankind to achieve his proper goal. We may be able to contemplate the goodness of creation, but what is that goodness but the way all creation works for the benefit of humanity? The goodness of creation reflects the goodness of the Creator, but what is the goodness of the Creator but his provident concern for humanity? Does God after all take pleasure in the whole creation for its own sake, or only for the sake of humanity?

This question is one on which Augustine himself is not as clear as we might hope. There is, however, some contribution to an answer in City of God book 12, chapter 4 . Augustine is answering the challenge that there are apparently some features of nature which are quite simply bad from the human point of view. They do us no good at all, in fact they do us harm. Augustine replies that if we think that these features of nature are bad we are taking too much of an anthropocentric point of view: we are considering natural things not in themselves but only from the point of view of their utility to mankind. Here utility is not the measure of goodness in creation; on the contrary we are to find value in creation in and for itself, regardless of our own benefit:

non itaque ex commodo uel incommodo nostro, sed per se ipsam considerata natura dat artifici suo gloriam. 
Creation, we may conclude, would be good and valuable even in the absence of any human being to appreciate either its beauty or its utility. It serves as a glory to its creator in its own right, not simply in virtue of instrumental value for humanity's spiritual developoment.

Not only is the anthropocentric viewpoint challenged in this chapter, but it is also envisaged that things might have value by contributing to the well-being of other creatures besides humanity. The heat of fire, or light too bright for human eyes, though harmful to men may be proper and helpful to other creatures.

Augustine's position results in paradox. Ask what the world is for and you get three equally correct answers: it is for the glory of God; it is for use by man; it is good for its own sake and for the sake of every individual and species within it. As in Plato man has a place in this scheme, but he has it only because he can look beyond himself to an end beyond the material world. In so far as the world is there to be used by mankind, it is focussed on humanity. But in so far as the use is directed to divine and not human ends, the world as a whole and humanity with it is focussed elsewhere.

\section{Conclusion}

The aim of this paper has been to show that the centrifocal material structure of the cosmos in Plato and Augustine does not correspond with a centrifocal value system, and that man's position of importance does not derive from the fact that he is peculiarly subject to gravity. On the contrary, the metaphysical and moral structure of reality is such that the centre of the material cosmos is the lowest point on the scale of overall importance. In this case marginality and not centrality in the physical world gives a thing value in the metaphysical world.

This is not to say that ideas had not shifted by the time of Copernicus and his successors. It may be that in fact the reluctance to remove the Earth from the centre of the universe at tha time was because that position was perceived as a privileged position that guaranteed mankind's rights over the rest of the world ${ }^{42}$ If so the reasons for keeping the Earth central had changed; in Plato and Augustine the Earth is central not to give it pride of place but to keep it securely in the lowest place, furthest from truth, being and eternity. ${ }^{43}$

ST ANNE'S COLLEGE, OXFORD

CATHERINE OSBORNE

\section{NOTES}

I. David Furley, The Greek Cosmologists I, The formation of the atomic theory and its earliest critics (1987).

2. Timaeus 17a-19a9. On the close parallels with the Republic see G. E. L. Owen 'The place of the Timaeus in Plato's dialogues', $C Q$ 3(1953) 79-95, pp. 89-90. 
3. $17 \mathrm{cl}-2$.

4. $27 \mathrm{a} 3-6$.

5. 27a7; cf. Critias 106b7. Critias is an Athenian, one of the Thirty Tyrants (or perhaps his grandfather).

6. 20a7-b7; Critias 108a5-bl. Hermocrates is the Syracusan general responsible for the defeat of the Sicilian Expedition. On the relevance of these allusions to Athens' defeat in the Peloponnesian War see Christopher Gill, Plato: the Atlantis story (1980). The Critias remains unfinished and the Hermocrates does not exist at all. This point concerns the internal expectations within this dialogue and has nothing to do with the chronological order of Plato's dialogues.

7. Timaeus $21 \mathrm{e}$.

8. $22 b$.

9. $23 \mathrm{~d} 7-\mathrm{e} 2$.

10. 24e-25a. The Timaeus emphasizes world-geography. Only in the Critias do we get a detailed account of the layout of things on Atlantis itself. In the Critias the capital city of Atlantis has a centrifocal layout, but neither the city, nor the fertile plain in which it is located, is at the centre of the island but at a mid-point on one coast (113c).

11. $23 \mathrm{c} 3-6,24 c 5-d 7,25 b 5-c 1$.

12. $17 \mathrm{al}$.

13. $20 \mathrm{~b} 1-7$

14. $19 \mathrm{~b}$ c. Note that Republic 9 raised the question of the ideal state in practice, $592 \mathrm{a} 10-\mathrm{b} 4$.

15. The point of this is not to say, as Cornford suggested (Plato's cosmology p. 20), that Plato means that natural science is a peripheral concern, only marginally relevant to his main interest which is morality and politics. Rather it indicates what relation does obtain between natural science, or politics, and the study of true being that is real science for Plato. Natural science is marginal, and myth, but these may actually give it an important status with regard to the truth to which it approximates. See, on the serious nature of Plato's science, G. E. R. Lloyd, 'Plato as a natural scientist', JHS 88 (1968) 78-92. On the status of 'verisimilar accounts', A. F. Ashbaugh, Plato's theory of explanation (1988).

16. Timaeus $33 \mathrm{~b} 2-7$.

17. $40 \mathrm{~b} 8-\mathrm{c} 3$.

18. $92 c 7-9$.

19. The Demiurge is presented as a logical conclusion from the status of the world as 'becoming', 28 a.

20. $28 \mathrm{c} 5-29 \mathrm{~b} 2$. 
21. The world is a likeness not a reflection. The model is works of art: $\varepsilon i \kappa \omega v, 29 \mathrm{~b} 2,92 \mathrm{c} 7$; $\mu i \mu \eta \mu \alpha$, $48 \mathrm{e} 6$.

22. $33 \mathrm{c}-\mathrm{d}$.

23. $33 \mathrm{~b}, 36 \mathrm{~b} 6-\mathrm{d} 7$.

24. $36 \mathrm{~d} 8-\mathrm{el}$.

25. $32 \mathrm{~d} 1-33 \mathrm{bl}, 29 \mathrm{~d} 7-30 \mathrm{a} 7$.

26. $34 c 4-6$.

27. At $36 \mathrm{c} 4-5$ the circle of the same is outermost. $39 \mathrm{a} 1$ is unclear.

28. 40a4-b4. Some of the gods, however, are located on the inner wandering spheres, and the earth too is a god, $40 \mathrm{~b} \mathrm{c}$. In addition there is a third class of gods, the gods of mythology, $40 \mathrm{~d} 6-41 \mathrm{a} 3$.

29. $41 \mathrm{a} 7-8,42 \mathrm{e} 6-7,69 \mathrm{c} 3-5$.

30. $41 \mathrm{e}$.

31. $41 \mathrm{c}$

32. $41 \mathrm{~d} 1-2$.

33. $42 \mathrm{~b} 5,90 \mathrm{e} 691 \mathrm{a}$. This view of women might seem surprising after the recapitulation of the Republic's teaching on equality for women, Timaeus $18 \mathrm{c} 1-4$.

34. $92 \mathrm{a} 2-7$.

35. $91 \mathrm{~d} 6-\mathrm{e} 1,46 \mathrm{c}-\mathrm{e} 2$.

36. Strictly speaking there can be no 'is' for non-eternal things, 37e3-38a1. Cf. Theaetetus $157 \mathrm{a} 7-\mathrm{c} 2$ and 182a-d. Owen (1953) 85-6.

37. A further candidate for marginal status between being and becoming is the 'receptacle', 50c7-el, 51a4-b2. On the ambiguous status of the receptacle and its place as a triton genos (48e, 52a) see J. Derrida, 'Chôra' in Poikilia: études offertes a J. P. Vernant (1987) 265-96. It is noteworthy that the account of the receptacle is roughly the midpoint of the dialogue (see Derrida 276). On the relation of chora to the same and the different see Luc Brisson, Le même et l'autre dans la structure ontologique du Timée de Platon (1974) 178-220.

38. Critias also claims truth for his story, which he calls a logos, not a muthos, 20d7-8; on the other hand in the Critias he is more cautious, likening his account to an artistic image (Critias 197a-e). In the context of the Timaeus it is clear that this truth claim is important. For a discussion of the status of the Atlantis story see Christopher Gill 'The genre of the Atlantis story' $C P 72$ (1977) 287-304. On the relation between genres of being and genres of discourse see J. Derrida (n.37) 266-7. 
39. De div, $Q Q .83 .30$.

40. De div. $Q Q 83.30$.

41. Tract. in Joh. 40.10 .

42. Plutarch preserves a tradition, which he attributes to Theophrastus (Quaest. Plat. 1006c; cf. Numa 1I) that Plato changed his mind and in later years removed the earth from the centre of the universe, on the grounds that such a position was 'not fitting'. At Numa 11 he implies that this was because the central body ought to be something great and dominating. Cf. also Chalcidius In Tim. ch. 100 and Theo Smyrnaeus Expositio 187.13-188.7: both witness to a sense of discomfort at the idea that the centre of bulk or the 'mathematical centre' should not also be the centre of life or vigour, nevertheless concluding that for Plato the sun, though off-centre, was really the 'heart' of the cosmos. Neither grasps Plato's vision that the centre of the sphere should be the least honourable place. See F. Solmsen 'A heliocentric interpretation of the Timaeus', Classical Weekly 37 (1944) 187-8.

43. I am grateful to Robin Osborne for criticism of the structure of an earlier version of this paper, causing me to abandon its once centrifugal format. Thanks are also due to the audience at the 1988 Triennial meeting of the Greek and Roman Societies for their constructive discussion, and particularly to Chris Gill, M. M. Mackenzie and Robin Waterfield for points they raised then and afterwards. 